\title{
Título da página electrónica: 1968 in Europe
}

URL: http://1968ineurope.sneakpeek.de

\section{Miguel Cardina}

\section{(2) OpenEdition}

\section{Journals}

Edição electrónica

URL: http://journals.openedition.org/rccs/680

DOI: $10.4000 /$ rccs. 680

ISSN: 2182-7435

\section{Editora}

Centro de Estudos Sociais da Universidade de Coimbra

Edição impressa

Data de publição: 1 junho 2008

Paginação: 224

ISSN: 0254-1106

Refêrencia eletrónica

Miguel Cardina, «Título da página electrónica: 1968 in Europe », Revista Crítica de Ciências Sociais

[Online], 81 | 2008, posto online no dia 01 outubro 2012, consultado o 22 setembro 2020. URL : http:// journals.openedition.org/rccs/680; DOI : https://doi.org/10.4000/rccs.680 


\section{Espaço Virtual}

\section{Título da página electrónica: Memória do Movimento Estudantil URL: http://www.memoriaestudantil.org.br}

Tal como é dito na nota de apresentação do projecto que está por detrás deste site, "a história do Brasil não seria a mesma se não fosse a actuação dos estudantes". De facto, o peso social destes e a visibilidade da sua militância cívica têm, desde há bem mais de meio século, marcado de uma forma indelével as diferentes etapas de transformação da realidade brasileira. Daí a importância da organização, da preservação e da divulgação dos múltiplos momentos e aspectos que integram a história do movimento estudantil brasileiro e o grande valor de um projecto como este, que visa fazê-lo recorrendo aos instrumentos e às possibilidades oferecidos pelos suportes electrónicos e pela Internet. Alguns dos conteúdos, de manifesta utilidade, comportam a recolha de dados sobre o movimento, a organização de uma cronologia, uma galeria de hiperligações, a oferta de informação bibliográfica diversificada e a disponibilização pública de toda esta informação. Mas outros revelam uma ambição capaz de transcender a dimensão do próprio site, procurando transformá-lo num instrumento em condições de dinamizar processos como o registo sistemático de depoimentos de activistas e a realização de uma campanha nacional de incentivo à doação de documentos, fotografias e outros registos relacionados com o tema. Pretende-se também ajudar a preparar a organização, no Rio de Janeiro, de um futuro Centro de Memória do Movimento Estudantil. O interesse deste projecto para a comunidade de investigadores, para o público em geral e para a continuidade do próprio movimento é inquestionável.

\author{
Rui Bebiano \\ ruibebiano@mail.telepac.pt
}

\section{Título das páginas electrónicas: Stoa - Ocupação USP - Greve 2007 e Ocupação da Reitoria da Universidade de São Paulo URLs: http://stoa.usp.br/ocupacaousp/weblog e http://ocupacaousp. noblogs.org}

O movimento estudantil da USP, que culminou em Maio-Junho de 2007 na ocupação da Reitoria da Universidade durante 50 dias, utilizou largamente os meios electrónicos e a blogosfera como meio de divulgação e debate. Estes dois blogues condensam um variado conjunto de informações que permitem seguir todo o processo da luta estudantil, incluindo diversos arquivos sobre a história da ocupação, o debate que decorreu nos media de São
Paulo e as controvérsias sobre as posições que adoptaram acerca das acções e greves que então dominaram a opinião pública paulista. Desde as reivindicações iniciais dos estudantes, às dificuldades do processo negocial com a reitoria, passando pelas ameaças policiais, os decretos do governador José Serra, as iniciativas culturais e conferências promovidas pelos estudantes, as discussões em torno dos esquemas organizativos e o papel das 
estruturas organizativas e dos partidos nesse processo, etc. $\mathrm{O}$ primeiro destes blogues continua activo e contém vários depoimentos, entrevistas e debates sobre temas universitários e os novos objectivos e propostas dos estudantes no período pós-ocupação. Ambos incluem opiniões plurais de diversos sectores, professores, estudantes, responsáveis institucionais e sindicais e ainda vários hiperligações que dão acesso a uma variedade de vídeos e gravações. Num contexto de dificuldade de mobilização do movimento estudantil em Portugal, vale a pena prestar atenção à realidade brasileira e a esta luta em particular, onde a questão das alianças entre a luta dos estudantes e a acção grevista e sindical de funcionários e professores reintroduziu no debate alguns ingredientes que remetem para o espírito do Maio de 68 .

\section{Elísio Estanque}

estanque@fe.uc.pt

\section{Título da página electrónica: 1968 in Europe URL: http://1968ineurope.sneakpeek.de}

Se os protestos estudantis ocorridos em Paris ou Praga durante o "longo ano" de 1968 são alvos de frequente evocação, bem menor é a visibilidade dos processos contestatários surgidos em outras paragens do território europeu, situadas em qualquer uma das metades criadas pela linha divisória do antigo muro de Berlim. Este site tem desde logo o mérito de apresentar cerca de uma vintena de cronologias, alinhadas por critérios geográficos ou temáticos, cuja leitura permite perceber o carácter transnacional destes movimentos, mas também o modo como eles foram adquirindo características específicas consoante o contexto interno em que se inseriam. Por outro lado, 1968 in Europe constitui igualmente uma plataforma electrónica comple- mentar a um livro homónimo, publicado recentemente por Martin Klimke e Joachim Scharloth, no qual se reúnem textos de vários investigadores sobre o impacto das contestações estudantis dos anos sessenta em diferentes países europeus. Assim sendo, esta página disponibiliza a introdução da obra e o posfácio, assinado pelo norte-americano Tom Hayden, antigo activista do SDS (Students for a Democratic Society) e ainda um vasto conjunto de hiperligações para fontes, arquivos e estudos sobre a época, para além de uma interessante lista de filmes dedicados ao período.

\section{Miguel Cardina miguelcardina@gmail.com}

